\title{
An Analysis of Efficiency Technique Level of Rural Bank by Using Data Envelopment Analysis (DEA)
}

\author{
Wini Welani, Nugraha, Heraeni Tanuatmodjo \\ Faculty of Economic and Business Education \\ Universitas Pendidikan Indonesia \\ heraenitanuatmodjo@upi.edu
}

\begin{abstract}
Purpose - The purpose of this research is to measure the efficiency technique level of Rural Banks in 20132014 by using a Data Envelopment Analysis (DEA) method, by BANXIA software. Design/methodology/approach - The approach used to choose the input and output is intermediation approach. The Input used is a factor of assets, deposits and personnel expenses. The output factors used are credit and other operating income. Findings -The use of the input and output of rural banks in the area of Bandung from the year 2013-2014 by using the DEA has not reached optimum efficiency. BPR scale efficiencies in the area of Bandung with DEA method is at the stage Decreasing Return to Scale. Originality/value - This study provides a basis for understanding efficiency in banking. This is a good contribution to the world's knowledge of financial management that addresses the banking efficiency and provide solutions to the problems faced by the banking industry in Indonesia, especially rural banks.
\end{abstract}

Keywords-Data Envelopment Analysis (DEA), Efficiency, Rural Bank

\section{INTRODUCTION}

The right and strategic financial institution to serve the banking service for society is BKR. The key to the success of BPR in the awarding of services to UMKM among others is the location of the RB which is closer to communities in need, service procedures are simple with a quick process, as well as the emphasis on the personal approach with the local society.

BPR is claimed to be able to survive in the face of the global economic crisis, which is happening at this time because BPR was instrumental in providing financing in the sector of UMKM throughout the area. BPR has a simple service procedure, quick process and credit schemes which are easier to adjust as well as the location that is spared throughout the rural and urban areas in comparison to the commercial banks. Given the magnitude of the role of the BPR, then efficiency is indispensable (Hendi, S and Tatik, 2010).

There are four factors that affect the efficiency of the company: (1) the efficiency of arbitration because of the economy, (2) the efficiency of the basic assessment of accuracy because its assets, (3) efficiency due to the financial institutions of the bank's ability to anticipate the risks that will arise and (4) the functional efficiency with regard to the mechanism of payments made by a financial institution" (Iswardono $s$. Permono and Darmawan, 2000:1-13). Thus, the quality development of the earning assets (asset) BPR becomes a very important aspect to maintain the stability of a bank.

Technical efficiency is only one component of overall economic efficiency. However, in order to achieve economic efficiency, a company should be technically efficient ". In order to achieve maximum profitability, a company must produce the maximum output with a certain amount of input (technical efficiency) and produces output with the right combination with a certain price level (allocative efficiency). (Kumbhaker, s. C Lovell UR, et.al., 2000),

A research advanced by Oral, $\mathrm{M}$ and R, Yolalan (1990) as well as Berger and Humphey (1991) revealed that the assessment of efficiency cannot be done partially such as measurement of the ratio of labor costs with revenues, but it should be taken into account throughout the entire output and input in there. So that, a more appropriate approach in the performance measurement of efficiency is to use the frontier approach to analysis of parametric and non-parametric analysis. The results of the study showed that the efficiency measurement which was carried out either by using nonparametric or parametric will show similar and relatively consistent result.

These last few years the calculation of financial institutions performance has focused more on frontier efficiency or $\mathrm{x}$ efficiency, which measures the deviation of financial institutions based on best practice or generally accepted on its frontier efficiency. The frontier efficiency from a financial institution is measured based on how the financial institutions performance relative to the best financial institution performance's mind of the industry. (Barr, r. Setal in Rusydiana, a.s, 2013:10)

Frontier approach can be differentiated into parametric and non-parametric approach. Parametric approach does a measurements by using a stochastic econometric and try to eliminate distractions from the influence of the deficiency. There are three parametric approaches to econometrics, namely: 1) Stochastic Frontier Approach (SFA), 2) Thick Frontier Approach (TFA), and 3) Distribution-free Approach (DFA). Meanwhile, the non-parametric approach with a linear program (Non-Linear parametric Programming Approach) performs a non-parametric measurements using a nonstochastic approach and tends to combine deficiency and distraction. It is built based on the discovery and observation of the population and evaluate the efficiency relative to the 
observed units. On the non-parametric method, an approach that can be used is Data Envelopment Analysis (DEA) and the Free Disposal Hull (FDH). (Baueret.al in Rusydiana, a. s., 1995:11).

Charnes, Cooper and Rhodes (1978) introduced the first DEA to calculate the level of efficiency. Linear programming is very dependent upon the population sample so that it tends to be far from the error specification. Then, developed by Denizer, URCevdetA.et.al (2000) which stated "DEA approach can also see how a unit decision makers (UPK) was doing his own performance so that the refinement can be efficient."

This study used Data Envelopment analysis calculation method (DEA) to calculate the level of efficiency that first introduced by Charnes, Cooper and Rhodes (1978). The data method was created as a tool for evaluation of the performance of an activity within a unit entity (Organization).

The DEA has some advantages, namely: 1) it can handle a lot of inputs and outputs, 2) it doesn't need an assumption of functional relationship between of input and output variables, 3 ) the units of economic activity compared directly with each other, 4) it may form a frontier line the best efficiency function over input-output variables for each sample, 5) inputs and outputs can have different units of measurement. (Rusydiana, a. s., 1995:36).

The measurement of efficiency using DEA method can be done by identifying units that were used as references which can help to find the causes and solutions of the deficiency. The advantage of using this approach is that the DEA does not require an explicit specification of the form function and require only a little structure to form the frontier efficiency.

Based on the description above, the research aims to know the description of the level of technical efficiency and scale efficiency of BPR in the area of Bandung by using DEA method.

\section{REVIEW OF THE LITERATURE}

An efficiency is defined as a comparison between output with input, or the amount generated from a used single input". A company can be considered efficient in utilizing the number of units that are less when compared to the number of used units of inputs than other companies to produce the same output, or use the same input unit that can produce a greater amount of output. (Suswadi in Rusydiana, a. s. (2013:39). It is usually associated with how the company achieves its goals. Therefore, the concept of efficiency is often seen from the cost aspect. The company always strives so that the level of charges is pressed to the minimal level to produce the desired output level in the process of transformation of inputs into outputs (Nurhandini, 2006).

The banking efficiency as a whole can be composed into the scale efficiency, the scope efficiency, the technical efficiency, and the allocative efficiency. A bank is considered to achieve efficiencies in scale when the bank is able to operate in a constant outcome scale (constant return to scale), while the efficiency of coverage is reached when the bank is able to operate at diversified locations. The efficiency of the allocation is reached when the bank was able to determine a wide range of output, which maximize profits, while the efficiency of the technique is essentially the relationship between inputs and outputs in a production process. A production process is said to be efficient if the certain amount of input used can generate maximum output or to produce certain outputs by using the most minimum input. (Ahmad Syakir Gift in Maflachatun, 2010:45)

Analysis of the frontier efficiency according to Berger and Humphrey in Sari, N (2010:34), the calculation of the performance of financial institutions is more focused to the frontier efficiency or x-efficiency, which measures the deviation of financial institutions based on best practice or generally accepted on the efficiency frontier

The efficient frontier analysis is quite superior to most of standard financial ratios used by regulators, manager of a financial institution or an industry consultant in analyzing financial performance. The efficient frontier is superior because of the size of the efficient frontier uses the techniques of programming or statistics that eliminates the influence of the differences in the inputs price and other exogenous market factors affects the standard performance or the ratio in order to get the best estimation based on the performance of the manager. For the frontier analysis, there are two approaches that can be used, namely the non-parametric and parametric. Parametric approach does a measurements by using a stochastic econometric and attempts to eliminate distractions from the influence of the deficiency (Sari, N, 2013:20). According to Rusydiana, a. s. (1995:12) parametric methods include Stochastic Frontier Approach (SFA), Thick Frontier Approach (TFA), and Distribution-Free Approach (DFA). A non-parametric method with linear program (Non parametric Linear Programming Approach) is a non-parametric measurements using a non-stochastic approach and tend to combine deficiency and distraction. Non-parametric methods include Free Disposal Hull (FDH) and Data Envelopment Analysis (DEA).

A non-parametric approach has several advantages compared to relative parametric techniques. In measuring efficiency, non-parametric approach identify units that are used as references which can help to find the cause and a way out of the deficiency, which is a major advantage in the managerial applications. A non-parametric approach does not require a complete specification of the form of the function that shows the relations of production and distribution of the observations. Parametric approach is highly dependent on the assumptions of production and distribution data. With the references of previous research, this study will be carried out using Data Envelopment Analysis (DEA). The DEA model was chosen because it is able to measure the efficiency in more general, has been widely used in a variety of research efficiency before and use the software that was used for data processing are relatively easy to obtain and operate.

According to W.W. Cooper et al (2011:1) "Data Envelopment Analysis (DEA) is a data-oriented approach for evaluating the performance of a set of peer entities called Decision Making Units (DMUs), which converts multiple input multiple output into a s". DEA is a non-parametric method 
used in measuring the degree of efficiency of a Unit of economic activity (UKE) ". (Firdaus, M. F and Hosen, M. N., 2013:172). DEA is a non-parametric approach which is based linear program (Linear Programming) and assisted by software efficiency packages, such as Banxia Frontier Analysis (BFA) and Data Envelopment Analysis for Warwick (WDEA). The point is that both the software will lead to the same result. The efficiency of banking techniques is measured by calculating the ratio between the output and the input. (Miller and Noulas in Sutawijaya, A and Sustainably, E.P., 2009)

Engineering measurement model based on the assumption of frontier approach, there are two DEA models that are commonly used, namely:

1. The DEA Model CCR (Charnes Cooper-Rhodes-1978) the assumption used is Constant Return to Scale (CRS). Some linear program are transformed into ordinary programs, linear primal or dual basis, such as:

$$
\begin{aligned}
& \text { Maximize: } \\
& h_{s}=\sum_{i=1}^{m} U_{i} Y_{i s}
\end{aligned}
$$

The limitation functions

$$
\begin{aligned}
& \sum_{i=1}^{m} U_{i} Y_{i r}-\sum_{j=1}^{n} V_{j} x_{j r} \leq 0, r=1, \ldots . ., N \\
& \sum_{j=1}^{n} V_{j} x_{j s}=1 \& U_{i} \text { dan } V_{j} \geq 0
\end{aligned}
$$

Efficiency in each DMU is calculated using linear programmatic by maximizing the output amoung calculated from DMU s. The constraints of input number must be the same as the one for DMU's, while the constraints of all banks, namely the calculated output minus the number of calculated input must be less or equal to 0 . This means that all banks will be at or below the reference of frontier performance which is the straight line that cuts the axis origin (Insukirdo in Knowing and Sustainably, 2009).

2. The Model of DEA BCC (Bankers, Charnesdan Cooper) the assumptions used in these models is the Variable Return to Scale (VRS). Some linear programs transformed into ordinary programs, linear primal or dual basis, such as:

\section{Maximize:}

$$
h_{s}=\sum_{i=1}^{m} U_{i} Y_{i s}+U_{0}
$$

With the limitation functions:

$$
\begin{aligned}
& \sum_{i=1}^{m} U_{i} Y_{i r} / \sum_{j=1}^{n} V_{j} x_{j r} \leq 0, r=1, \ldots . ., N \\
& \sum_{j=1}^{n} V_{j} x_{j s}=1 \& U_{i} \operatorname{dan} V_{j} \geq 0
\end{aligned}
$$

Where Uo is a line that can have a positive or negative value.

As has been explained above, there are two DEA models that are often used for measuring efficiency, i.e. the CCR and the BCC. Charnes, Cooper and Rhodes (1978) developed a model of DEA method with constant return to scale (CRS) mthod and further developed by Banker, Charnes and Cooper with variable return to scale (VRS) which is finally known as CCR (Charnes-Cooper-Rhodes) model and BCC (BankerCharnes-Cooper) (Amrillah, 2010).

CCR assumes the presence of CRS, in which the assumption of CRS is proportional changes at all unit levels will result in the same proportional change in the output level. While the BCC assumes the existence of the VRS. It is the assumption that all measured units will make changes at different levels of output and the existence of a presumption that the production scale can affect efficiency. (Sutawijaya, A and Sustainably, e. p., 2009)

In general, a business or UPK like banks, have the characteristics that are similar one another. However, each bank usualy has various size and production level. Halini suggests that the bank size has an important role that determines the relative efficiency or inefficiency. The CCR model reflects (multiplication) the technical and scale efficiency, while the BCC model only reflects the technical efficiency, so that the relative scale efficiency is the ratio of CCR efficiency model and BCC model.

\section{$\mathrm{Sk}=\mathrm{qk}, \mathrm{CCR} / \mathrm{qk}, \mathrm{BCC}$}

If the value of the $S=1$, it means that the UPK operates at the best scale efficiency measure. If the value of $S$ is less than one mean still there are inefficiencies of scale in UPK. So, the value of (1-S) indicates the level of inefficiency of the scale of UPK. So, UPK which is efficient with CCR means its scale is also efficient. Whereas, UPK which is efficient with BCC model but inefficient with CCR model means it has inefficiencies scale. This is because the UPK technically efficient, so infusions are derived from the scale. (Aam Slamet Rusydiana, 2013:23-24).

According to Ahmed, e. \& Rohmana, y. (2007:148), the returns to scale are distinguished into three important types, namely:

\section{Constant Returns to Scale}


This shows the case if all input changes cause an increase in output by the same amount, or all of the factors of production are added equally.

\section{Decreasing Returns to Scale}

Shows the case if all inputs increase by the same amount causes an increase in the total output that are less proportional.

\section{Increasing Returns to Scale.}

Shows a case that is if the increase of all input cause an increase in bigger output. This shows that the increase of all input cause an higher increase in output.

\section{RESEARCH Methodology}

The object of this research did an analysis of the efficiency of the BPR uses the DEA in the period of 2013-2014. For its unit analysis such as total deposits, total interest expenses, personnel/burden of labor as an input factor total credit given, interest income, non-interest income, shareholders ' equity is added to total income as factor output

The research method used is the quantitative analysis about efficiency of BPR by using DEA. This research was done for 2 years, starting from 2013 to 2014 so a period of research is time series. According to William g. Z, et al. (2009:280) "design time series is used for an experiment investigating long-term structural changes".

The population of this research is $56 \mathrm{BPR}$ in Bandung area listed in bank Indonesia for period 2013-2014. While the sample is a part of the population that can represent existing populations. In this study, the sample used is 32 BPR in Bandung area registered in BI and have the balance sheet report and full profit/loss financial reports in the period of 2013-2014.

\section{FINDINGS AND DISCUSSIONS}

Analysis of the efficiency of the method using DEA model with VRS for a period of 2 years of BPR in Bandung District still under $100 \%$ (inefficient). Calculation of efficiency of techniques using the DEA showed $64 \%$ of BPR in Bandung area has reached $100 \%$ efficiency, $15 \%$ BPR achieve efficiencies of $90 \%, 6 \%$ BPR reaches $80 \%, 12 \%$ up to $70 \%$ BPR, BPR and $6 \%$ achieved a $60 \%$ efficiency.

Thus, from 32 in the Bandung area BPR became the sample of this research there were $21 \mathrm{RB}$ who achieve $100 \%$ efficiency, the efficiency reaches 5 BPR $<90 \%, 2$ BPR which reached $80 \%$ efficiency $<, 3 \mathrm{RB}$ to reach the $70 \%$ efficiency $<$, and 1BPR to reach efficiency $<60 \%$. With those results then the BPR in Bandung area has not fully reach optimum efficiency.

In the meantime, the efficiency Scale BPR in Bandung area based on non-parametric frontier approach with the method of DEA (Data Envelopment Analysis), showed 34\% of BPR in Bandung District have reached efficiencies of 1 , while the remaining 66\% BPR in Bandung District have yet to achieve efficient scale is 1 . It means that 32 of BPR in the Bandung area being sampled in this study, only $11 \mathrm{RB}$ to reach the efficiency scale is 1 , while 21 other BPR still under the efficiency scale $>1$.

With those results, then the average efficiency of BPR in Bandung District scale is located on the conditions of business scale decreases (Decreasing Return to Scale) which means an increase in all inputs with the same number of causes an increase in the total output are less proportional. The results of the calculation of the efficiency of the technique and the scale using the DEA showed that the efficiency of BPR in Bandung area by 2013-2014 have not yet reached the optimum efficiency.

The results of the calculation of the efficiency of the technique and the scale using the DEA showed that the efficiency of BPR in Bandung area by 2013-2014 have not yet reached the optimum efficiency. Research is in line with previous research among them with the results of the research of the Komaryatin (2007), where the results of his research that $75 \%$ of BPR in the former presidency of Starch, East Java (2002-2004) is not efficient. This research is also in line with dik Kusumawardhani, d. (2008) investigated the levels of health and efficiency of BPR in East Java, the results of his research BPR in East Java less efficient. Further research undertaken Hartono (2008) research results is of Diana that $80 \%$ of BPR in Jabodetabek (2005-2007) is not efficient. Mongid, A and M's Unclean, i. (2010) is also researching on technical and sale efficiency of Indonesian Banks, the results of his research the Urals declared BPR in Indonesia from 20062007) is not efficient. Subsequent research conducted by biodiversity, a. t. (2011) that examines the technical efficiency analysis of the regional company BPR/BKK in Central Java province, with the results of research that the degree of efficiency of PD. BPR/BKK in Central Java in 2008 on a stage production and intermediation have not reached $100 \%$. Ardilho, N (2014) that examines the comparative analysis of efficiency between conventional and BPR BPR syariahdi of Surakarta by using DEA, the results of his research stating that BPR who experience the highest admission to inefficiency in the category of BPR conventional. Subsequent research conducted by Gunanta, d. h. (2014) that examines the level of determination the efficiency analysis of BPR in Medan, the results of his research stating that the entire BPR residing in Medan has yet efficient.

Meanwhile, the research of efficiency of the BPR uses the DEA with different results is done by the Rustandar and Nugraha, I (2014) are researching on Measuring Competitiveness Of The Ural Indonesia Banks Alt The Ude Level Of Productive Asset Efficiency: A Data Envelopment Analysis Approach (A Chase St Ural Banks In the District Of Majalengka) and Majalengka BPR research results from the years 2009-2013 (efficient > 97\%).

Refer to the results of a study conducted by Rustandar and Nugraha, I (2014) that refers to strata of urban areas or locations research, the difference in the results of such research because of the competitiveness of BPR is correlated with the location of the area of operations. Competitiveness of BPR will be higher in rural areas, whereas in metropolitan cities such as 
Jakarta, the competitiveness of BPR will decrease. Then the results of this study are consistent with studies about the efficiency of the BPR uses the DEA that has already been done before in Indonesia.

\section{CONCLUSION AND SugGestions}

The results of the BPR efficiency analysis in Bandung area 2013-2014 using the Data Envelopment Analysis (DEA) has not reached optimum efficiency yet because out of 32 BPR there are 10 BPR in the area of Bandung which has not yet reached the level of technical efficiency of $100 \%$.

The efficiency of scale efficiency of BPR in Bandung area 2013-2014 based on the non-parametric frontier approach by DEA (Data Envelopment Analysis) method are in a declining business scale conditions (Decreasing Return to Scale) which means that the increase of all inputs within the same number causes an increase of the less proportional total output.

\section{REFERENCES}

[1] Ahman, E. \& Rohmana, Y. (2007). Pengantar Teori Ekonomi Mikro. Bandung: Laboratorium Ekonomi dan Koperasi.

[2] Ariwinandi, F. (2014:16). Pengaruh Kinerja Bank-Bank di Indonesia Dengan Menggunakan Metode Data Envelopment Analysis. (Tesis). Magister Manajemen Universitas Indonesia Jakarta.

[3] Berger, A. N \& Humprey, D.B. (1991). The Dominance Of Inefficiency Over Scale and Product Mix Economies 2 (8): hlm. 117-148.

[4] Charnes, A. dkk. (1978).European Journal of Operation Research, Measuring the Efficiency of Decision Making Units 2 (6), hlm. 44, 429.

[5] Cooper, T.G. dkk. (2002). Semen analysis and external quality control schemes for semen analysis need global standardization. Int J Androl2(5):306-311.

[6] Denizer,CevdetA.,et.al.(2000),Measuring Banking Efficiencyin the Preand Post LiberalizationEnvironment: Evidencefrom theTurkish Banking System, WorldBank. Paper 2476

[7]

[8] Firdaus, M. F. \& Hosen, M. N. (2013). Buletin Ekonomi Moneter Dan Perbankan, Efisiensi Bank Umum Syariah Menggunakan Pendekatan Two-Stage Data Envelopment Analysis, 16(2), hlm. 186, 167.

[9] Hadad, M.D. dkk. (2003). Analisis Efisiensi Industri Perbankan Indonesia: Penggunaan Metode Non Parametrik Data Envelopment Analysis. Buletin Ekonomi Moneter Perbankan. Bnak Indonesia Research Paper.
[10] Hendi, S \& Tatik. 2010. Analisis Efisiensi Bank Perkredditan Rakyat di Kota Semarang Dengan Pendekatan Data Envelopmen Analysis. Jurnal Ekonomi dan Bisnis, Universitas Universitas Dipenogoro, 3 (1), hlm. $41-48$.

[11] Iswardono S. P \& Darmawan. (2000). Analisis Efisiensi Industri Perbankan di Indonesia tahun 1991-1996. Jurnal Ekonomi dan Bisnis Indonesia XV1, 15 (1), hlm. 34-37.

[12] Kumbhakar, S.C., C.A.K. \& Lovell (2000), Stochastic Frontier Analysis. Cambridge: Cambridge University Press.

[13] Mohamed, M. (2007). Industrial Management \& Data Systems, Benchmarking top Arab Banks Efficiency Through Efficient Frontier Analysis, 107 (6), hlm 802- 823.

[14] Maflachatun. (2010).Analisis Efisiensi Teknis Perbankan Syariah di Indonesia Dengan Menggunakan Metode Data Envelopment Analysis (DEA). (Skripsi). Universitas Diponogoro, Semarang.

[15] Mokhtar, H. S. A., Abdullah, N., \& Alhabshi, S. M. (2008). Efficiency and competition of Islamic banking in Malaysia. Humanomics, 24(1), hlm 22 .

[16] Nurhandini. (2006). Analisis Efisiensi Industri Perbankan di Indonesia Dengan Metode Non-Parametrik Dana Envelopment Analysis. (Skripsi). Ekonomi Universitas Indonesia, Depok.

[17] Oral, M. \& R, Yolalan. 1990. An Emperical Study on Measurement Operating Ingciency and Profotability of Bank Branches. European Journal of Operational Research, 4(6), hlm. 282-94.

[18] Rusydiana, A. S. \& Tim Smart Consulting. (2013). Mengukur Tingkat Efisiensi dengan Data Envelopment Analysis (DEA): Teori dan Aplikasi. Bogor: Smart Consulting.

[19] Sari, N. (2010). Analisis Tingkat Efisiensi Perbankan Syariah Dan Faktor Internal Eksternal Yang Mempengaruhinya. (Skripsi).Universitas Negeri Islam Syarif Hidayatullah, Banten.

[20] Sufian, F. \& Muzafar, S. H. (2010). International Journal of Development Issues, Developments in the efficiency of the Thailand banking setor a DEA approach, 9 (3), hlm. 226 - 245.

[21] Sufian, F. (2011). An International Journal, Benchmarking the efficiency of the Korean banking sector: a DEA approach, 18 (1), hlm.107 - 127.

[22] Sutawijaya, A. dan Lestari, E. P. 2009. "Efisiensi Teknik Perbankan Indonesia Pasca Krisis Ekonomi: Sebuah Studi Empiris Penerapan Model DEA". Jurnal Ekonomi Pembangunan, 10(1).

[23] Tecles, P. \& Tabak, B. 2010. Determinants of bank efficiency: The case of Brazil. European Journal of Operational Research, 207(3), hlm. 15871598 .

[24] William, G. Z. E. A. (2009). Business Research Methods 8 th edition. South Western: College Pub.

[25] W.W. Cooper et al. 2011. Handbook on Data Envelopment Analysis, International Series in Operations Researh\& Management Science 164, DOI 10.1007/978-1-4419-6151-8_1, Spingerscience+business media, LLC 2011 